Article

\title{
Physical Properties of Dairy Manure Pre- and Post-Anaerobic Digestion
}

\author{
Hui Wang, Horacio A. Aguirre-Villegas * ${ }^{\mathbb{D}}$, Rebecca A. Larson and Asli Alkan-Ozkaynak \\ Department of Biological Systems Engineering, University of Wisconsin-Madison, Madison, WI 53706, USA \\ * Correspondence: aguirreville@wisc.edu
}

Received: 22 May 2019; Accepted: 29 June 2019; Published: 3 July 2019

\begin{abstract}
Manure characteristics change through processing, including anaerobic digestion (AD). These changes can alter handling of manure during downstream operations. This study analyzed the density, total solids (TS) content, and volatile solids (VS) content of pre-digested and anaerobically digested dairy manure from seven dairy farms in Wisconsin. The density of pre-digested manure increased from 990 to $1065 \mathrm{~kg} \mathrm{~m}^{-3}$ as the TS level increased from $1.5 \%$ to $13.0 \%$. Density and TS for pre-digested manure from facilities using separated solids as bedding were related with a linear model for TS ranging from 1.5\% to $13.0 \%$ and with a polynomial model for TS ranging from $1.5 \%$ to $50 \%$. The model shows that density decreases with an increasing TS content when TS is greater than $8.0 \%$. Manure from dairy facilities that used sand bedding had a VS/TS ratio of 0.87 . This ratio was higher than the ratio when manure solids were used as bedding $(0.81)$ and when food waste was incorporated into the digester (0.77). This study also provides a simple methodology to estimate biogas yield by using the density of pre- and post-digested manure.
\end{abstract}

Keywords: anaerobic digestion; dairy manure; density; solid content

\section{Introduction}

Manure management is a critical activity for the economic and environmental sustainability of dairy farms. Manure can improve soil health and provide valuable nutrients for crop production when land applied [1]. However, the handling of manure can also be costly and lead to negative environmental impacts [2,3]. The most common utilization method for manure is land application, which costs approximately $\$ 306$ per cow per year to store, haul, and land apply [4]. In addition, manure is responsible for nearly $7 \%$ of both agricultural methane $\left(\mathrm{CH}_{4}\right)$ and nitrous oxide $\left(\mathrm{N}_{2} \mathrm{O}\right)$ emissions [5]. As a result, there has been increased attention to developing and implementing processing technologies that enhance the economic value of manure and reduce the related environmental impacts [6,7]. Anaerobic digestion (AD) is a common manure processing technology that can achieve both goals [8]. $\mathrm{AD}$ systems can use animal manures to produce biogas, which typically contains $50 \%$ to $65 \% \mathrm{CH}_{4}$ and can be collected and used for direct burn applications, converted to electricity, or compressed for use as a transportation fuel [9]. In addition, AD has environmental benefits as it reduces odors, greenhouse gas (GHG) emissions, and pathogens $[10,11]$.

The physical properties of manure, such as total solids (TS), volatile solids (VS), and density, are important in designing and operating manure handling and processing systems [12]. For example, the TS content will determine transportation options to move manure through the collection, processing, storage, and application cycle. The VS loading rate is a key design parameter for biogas production in AD systems [13]. Maximizing biogas production is important for increasing the availability of energy to use on-farm or sell as an additional source of income to the farmer. Finally, knowing the manure density is important to estimate operational volumes. Farmers can use this knowledge to make technology selections and operational decisions to increase efficiency and decrease costs. These data 
are also important for researchers and engineers to determine design parameters, such as storage volume, digester volume, and power capacity, among others. Moreover, these design parameters are important for models predicting biogas production [14] and environmental impacts from manure management [13]. This study goes one step further and develops an equation relating the physical characteristics of manure to facilitate representative data generation to be used by process-based, economic, and life cycle assessment (LCA) models.

Determining the relation between manure TS and density has been studied by researchers in the past, but many of these studies have focused on unprocessed manure, solid manure, and compost [15-17]. Houkom et al. [18] evaluated thermal conductivity, specific heat, and bulk density of fresh beef cattle manure in relation to moisture content to estimate thermal diffusivity. The authors sampled manure at TS contents ranging from $15 \%$ to $75 \%$ and developed a polynomial relation to predict density of manure according to moisture content. Chen [19] presented engineering properties of beef cattle manure including density, rheological properties, specific heat, and thermal conductivity. The author found that manure density increases gradually for TS from $0 \%$ to $50 \%$ and has a sharp drop when TS increases above $50 \%$. This drop might be attributed to the large void space in manure at these TS levels. Achkari-Begdouri and Goodrich [20] analyzed the bulk density, specific heat, and thermal conductivity of Moroccan dairy manure with respect to TS content. The authors analyzed samples with TS contents between $2.5 \%$ to $12.0 \%$ at temperatures between 20 and $60{ }^{\circ} \mathrm{C}$. Findings showed that density of manure increased when TS content increased from $0 \%$ to $14 \%$. The authors concluded that bulk density of cattle manure is a function of TS content and void spaces. However, when manure has less than $16 \%$ TS, it contains liquid and solid phases with no void spaces. More recently, Landry et al. [21] developed a relationship between manure density and TS content, but focused on manure with a high TS content from $10 \%$ to $50 \%$. A summary of previous studies that related TS content and density of animal manures is presented in Table 1.

Table 1. Summary of studies that related total solids (TS) content and density of animal manures.

\begin{tabular}{|c|c|c|c|}
\hline Manure Studied & Equation or Value Predicting Density of Manure & $\begin{array}{c}\text { TS } \\
\text { Range }\end{array}$ & Authors \\
\hline Beef & $\begin{array}{l}\rho=16.02\left(20.41-0.3648 M+0.01972 M^{2}+0.00001036 M^{3}-\right. \\
0.000001304 M^{4} \\
\text { where: } \rho=\text { bulk density }\left(\mathrm{kg} \mathrm{m}^{-3}\right) ; \mathrm{M}=\text { moisture content }(\%)\end{array}$ & $15-75 \%$ & Houkom et al. [18] \\
\hline Beef & $\begin{array}{l}\rho=\frac{998}{1-0.00345 T S} \\
\text { where: } \rho=\text { bulk density }\left(\mathrm{kg} \mathrm{m}^{-3}\right) ; \mathrm{TS}=\text { total solids }(\%)\end{array}$ & $0-16 \%$ & Chen [19] \\
\hline Dairy, sheep, pig, poultry & $\begin{array}{l}\rho_{\text {poultry and pig }}=-0.0235 \mathrm{TS}^{3}+1.19 \mathrm{TS}^{2}-11.2 \mathrm{TS}+1000 \\
\rho_{\text {dairy }}=0.0367 \mathrm{TS}^{3}-2.38 \mathrm{TS}^{2}+14.6 \mathrm{TS}+1000 \\
\rho_{\text {sheep }}=0.0086 \mathrm{TS}^{3}-0.873 \mathrm{TS}^{2}+8.9 \mathrm{TS}+1000 \\
\text { where: } \rho=\text { bulk density }\left(\mathrm{kg} \mathrm{m}^{-3}\right) ; \mathrm{TS}=\text { total solids }(\%)\end{array}$ & $10-50 \%$ & Landry et al. [21] \\
\hline Dairy & $\begin{array}{l}\rho_{\text {dairy }}=0.7026 \mathrm{TS}^{2}-58.132 \mathrm{TS}+1407.40 \\
\text { where: } \rho=\text { bulk density }\left(\mathrm{kg} \mathrm{m}^{-3}\right) ; \mathrm{TS}=\text { total solids }(\%)\end{array}$ & $16-50 \%$ & Landry et al. [22] \\
\hline Dairy & $\begin{array}{l}\rho_{\text {dairy }}=162.3 T S-159.3 \\
\text { where: } \rho=\text { bulk density }\left(\text { ton } \mathrm{m}^{-3}\right) ; \mathrm{TS}=\text { total solids }(\%)\end{array}$ & $0-16 \%$ & Houlbrooke et al. [23] \\
\hline
\end{tabular}

The physical characteristics of manure depend on multiple factors and practices before and after excretion. These factors include animal diet, animal type, manure collection and storage systems, processing technology, and water or other by-products added to the manure stream [24]. These practices have changed significantly in the last two decades [25], and this could have an impact on the manure density results presented by the studies listed above, as well as the relationship between manure density and TS. Dairy cattle today produce much more milk and are fed more grains for supplying energy [26]. Many facilities have also incorporated manure processing and storage which may have an impact on previously collected data. Manure characteristics can also change from one handling stage to the other, especially if there is manure processing such as AD. Scherer et al. [27] measured an $80 \%$ VS degradation during a two-stage AD process. The breakdown of organic compounds changes the composition of TS and thus, the density of manure after AD. Sampling manure at each stage from 
excretion to land application can become costly and time intensive for preliminary assessments and models. As a result, multiple dairy related LCA studies that evaluated the contribution of manure to different environmental impacts assumed no variation of the physical characteristics across manure stages [28-30]. This assumption can affect the precision of estimations given that some environmental impacts are directly related to manure characteristics. For example, $\mathrm{CH}_{4}$ and ammonia $\left(\mathrm{NH}_{3}\right)$ emissions from manure storage are highly dependent on VS content and surface area [13]. If physical changes in manure are not accounted for, modeled emissions of undigested and post-digested manure would be similar, which is not the case [10].

The aim of this paper is to relate manure TS to density for current dairy farming practices, particularly for those introducing AD. To better determine the density of manure pre- and post-digestion, the density, TS, and VS of manures were analyzed. These relationships and parameter changes are critical for planning decisions, infrastructure designs, evaluating equipment performance, and in developing models used for predictive purposes.

\section{Materials and Methods}

Pre-digested and post-digested manure samples were collected from seven Wisconsin dairy farms with AD. Dairy cows were housed in free-stalls, with digested and separated manure solids used as bedding on six farms (farms A, C-G) and sand bedding used on one farm (farm B). At all sites, after excretion, dairy manure (both urine and feces) was collected from the barns with a scrape system and stored in a collection pit for less than $24 \mathrm{~h}$ before pumping into the digester. Farm $\mathrm{F}$ incorporated food waste with the manure, also known as co-digestion, and farm $\mathrm{G}$ added chopped straw to the digester influent stream to produce more bedding [31]. All farms had modified plug-flow digesters, which are defined flow-path digesters with mixing provided along the flow, except farm A and F which had completely mixed systems. All digesters were operated at mesophilic temperatures and were designed for retention times from 21 to 30 days.

Samples were collected from both the collection pits before digestion and directly from the effluent line out of the digester. All samples were stored at $4{ }^{\circ} \mathrm{C}$ until analysis was completed. Prior to analysis, samples were agitated for $3 \mathrm{~min}$ using a drill mixer to ensure the incorporation of any settled solids. Bulk density was measured based on the sample mass in a $100 \mathrm{~mL}$ graduated cylinder. TS and VS were determined following gravimetric procedures found in standard methods [32]. All samples were initially analyzed for TS content (Table 2). Subsamples were then prepared with $1.5 \%, 3.0 \%, 4.5 \%, 6.0 \%$, $7.5 \%, 9.0 \%, 10.5 \%, 12.0 \%$, and $13.5 \%$ TS levels by either diluting with deionized (DI) water or oven drying at $105^{\circ} \mathrm{C}$. Additional pre-digested samples were collected from farm H, I, and J as excreted and oven dried. Subsamples with $16 \%, 18 \%, 20 \%, 25 \%, 33 \%$, and $50 \%$ TS were made by adding DI water to the dried manure. Actual TS content was then verified for diluted or dried subsamples. Since the verified TS level for pre-digested and post-digested samples on each farm were not equal, the VS destroyed in this study was calculated by the difference between the linear model at a TS level of $8 \%$ which is a common TS content for the influent for mixed plug-flow digesters in Wisconsin [31].

Table 2. Farm management practices and total solids (TS) content of undiluted manure.

\begin{tabular}{cccccc}
\hline Farm ID & Substrate & Bedding Type & Digester & Pre-Digested TS (\%) & Post-Digested TS (\%) \\
\hline A & Manure & Manure solids & Complete mix & 10.4 & 8.4 \\
B & Manure & Sand & Plug-flow & 6.6 & 6.0 \\
C & Manure & Manure solids & Plug-flow & 8.0 & 5.0 \\
D & Manure & Manure solids & Plug-flow & 6.4 & 5.1 \\
E & Manure & Manure solids & Plug-flow & 5.5 & 4.4 \\
F & Manure and food waste & Manure solids & Complete mix & 7.1 & 7.6 \\
G & Manure and chopped straw & Manure solids & Plug-flow & 7.6 & 6.2 \\
H & Excreted manure & NA & NA & 15.4 & NA \\
I & Excreted manure & NA & NA & 15.2 & NA \\
J & Excreted manure & NA & NA & 12.8 & NA \\
\hline
\end{tabular}

NA: not applicable. 
The Pearson's chi-squared test was used to evaluate if there are statistical differences $(p<0.05)$ in density and TS content in manure between farms. Data for pre-digested and post-digested manure were analyzed separately. Each dataset was fit to a linear regression model with density as the dependent variable and the verified TS content as the independent variable. Chow tests were performed to select the data that could be used to develop a general model between density and TS content. These tests indicate whether the coefficients in two linear regressions on different data sets are equal. The final statistical model was selected using Akaike's information criterion (AIC) forward stepwise. The impact of VS on density was also evaluated for pre- and post-digested samples separately. All the statistical analyses were conducted using R 3.0.1 [33].

\section{Results}

\subsection{Density versus Total Solids}

The linear models from the five farms that used manure solids as bedding and did not incorporate any off-farm wastes into their system were not significantly different and could be grouped together to develop one equation. Farm B (which used sand bedding) and farm F (which incorporated food waste as a co-digestion feedstock) were analyzed separately as they were significantly different than the rest. Farm B had a statistically significant higher average density at $1027 \mathrm{~kg} \mathrm{~m}^{-3}$ while farm $\mathrm{F}$ had a statistically significant lower density at $997 \mathrm{~kg} \mathrm{~m}^{-3}$ compared to the remaining farms.

Figure 1 shows that manure density increased with increasing TS levels from 1.5\% to $13.5 \%$. The values varied within a range of 990 to $1065 \mathrm{~kg} \mathrm{~m}^{-3}$ for pre-digested manure. The density of manure that contained sand and food waste did not follow the same trends as the other farms as shown in Figure 1. The density of manure with sand bedding was higher than all the other farms at each TS level, as sand has a higher relative density (1370 to $2323 \mathrm{~kg} \mathrm{~m}^{-3}$ ) than organic compounds in manure $\left(400 \mathrm{~m}^{-3}\right)$ [34].



Figure 1. Density of pre-digested manure as a function of total solids (TS) content.

The trend of increasing density with increasing TS contents (from $2.5 \%$ to $14.2 \%$ ) for undigested manure is in agreement with results published by Achkari-Begdouri and Goodrich [20]. The authors generated a linearly increasing model for undigested beef manure with a TS range of $2.5 \%$ to $14.2 \%$, as shown in Figure 2. The undigested manure density results are higher than those determined by Landry et al. [22], who reported undigested dairy manure density for TS content ranging from $16.7 \%$ to 
47.7\%. The authors observed a decrease in density from 637 to $199 \mathrm{~kg} \mathrm{~m}^{-3}$ until $44.4 \%$ solids, when the density values increased back to $238 \mathrm{~kg} \mathrm{~m}^{-3}$ at $47.7 \%$ solids level.

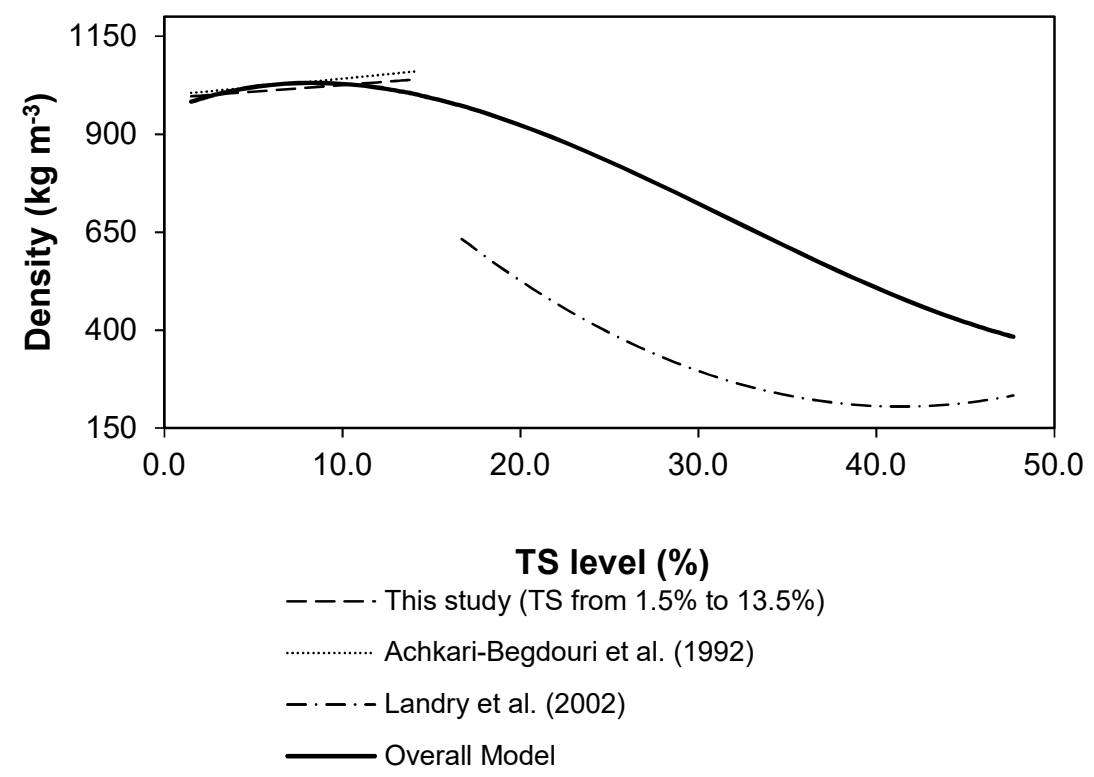

Figure 2. Comparison of three models relating density to TS content for manure only (pre-digestion).

The overall model considers samples only from farms A, C-G.

When examining the $1.5 \%$ to $13.5 \%$ TS results from this study with the $16.7 \%$ TS and higher results from Landry et al. [22], it is apparent that the unprocessed dairy manure density reaches a critical maximum value after which the density value starts to decrease. Figures 2 and 3 fit a model to data from this study as a function of TS ranging from $1.5 \%$ to $50 \%$. This model includes the additional samples for pre-digested dairy manure (farms $\mathrm{H}, \mathrm{I}$, and J) and the samples of the five farms that use manure solids as bedding, excluding farm $\mathrm{B}$ (using sand as bedding) and farm $\mathrm{F}$ (co-digesting manure with food waste). In this third order polynomial equation, the density increases until it reaches a critical point, $8.0 \% \mathrm{TS}$, where void space is created, and the density begins to drop.

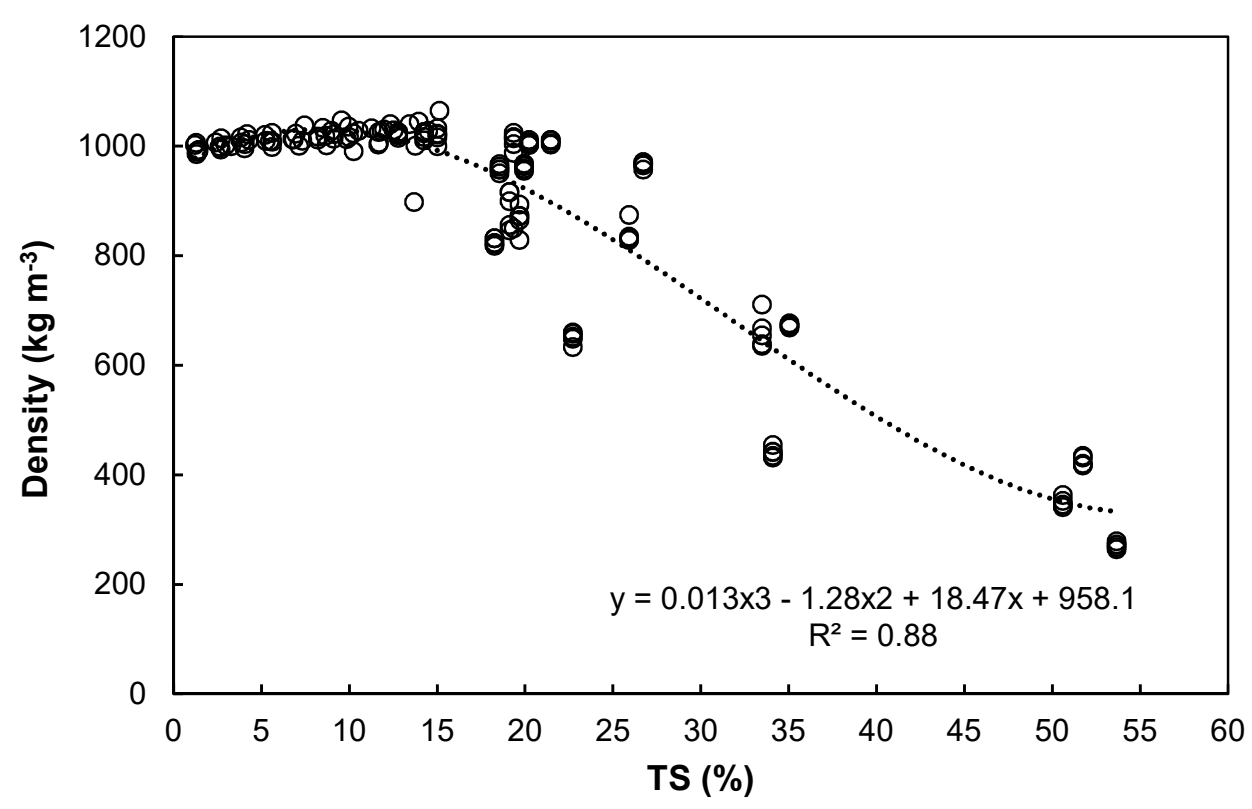

Figure 3. Density of pre-digested manure (farms A, C-G) as a function of TS content. 
Unlike pre-digested manure, the average density of post-digested manure at each farm is widely distributed with no significant differences. This change could be a result of the digestion process, which converts the digestible organic compound to biogas. The density of manure from farm $B$ remains higher due to its sand content, but the differences are not statistically significant. Even though sand was removed before the digestion process, studies have reported that up to $3 \%$ of the sand may have entered and settled in the digester causing the large range of TS content [10]. The post-digested manure density also increased with increasing TS content ranging from 990 to $1056 \mathrm{~kg} \mathrm{~m}^{-3}$, as shown in Figure 4. Data from farms A through F were used to develop one regression model while farm $G$ was assessed separately according to Chow test results which indicated that farm $G$ was significantly different. The lower density value of post-digested manure from farm $G$ could be a result of the lower density of the chopped straw added in the digester [35].

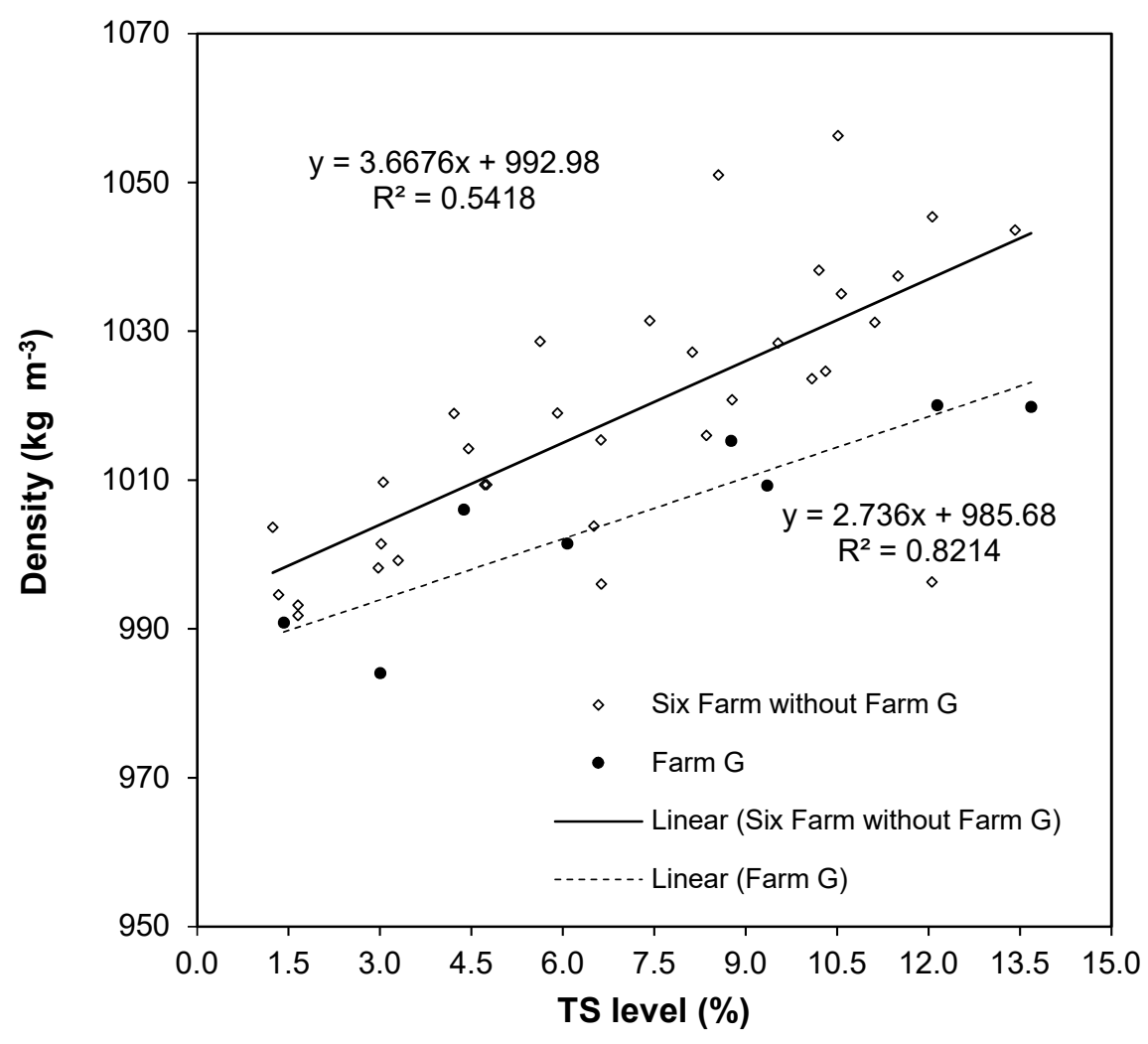

Figure 4. Density of post-digested manure as a function of total solids content.

\subsection{Density versus Volatile Solids}

Density increased linearly with increasing VS content, as described in Figure 5. The similarity of density versus TS and VS content for pre-digested manure could be explained by a relatively constant VS fraction in TS for farms that have manure only. Farm B had a lower VS to TS ratio (VS/TS) of 76.6\% due to the sand bedding, while farm $\mathrm{F}$ that incorporated food waste had a higher VS/TS ratio of $87.5 \%$ compared with the remaining five farms that had a VS/TS ratio of $81.2 \%$ for pre-digested manure. This difference could be explained by the low volatile fraction in sand and relative higher volatile fraction in food waste compared to samples containing only manure. The VS content of food waste can double the VS content of manure, which means a higher energy content [36]. The density of manure with sand bedding was greater than all the other farms at low VS level, but density was decreased at greater VS levels. The density of manure with added food waste was less than the other farms for every VS level. 


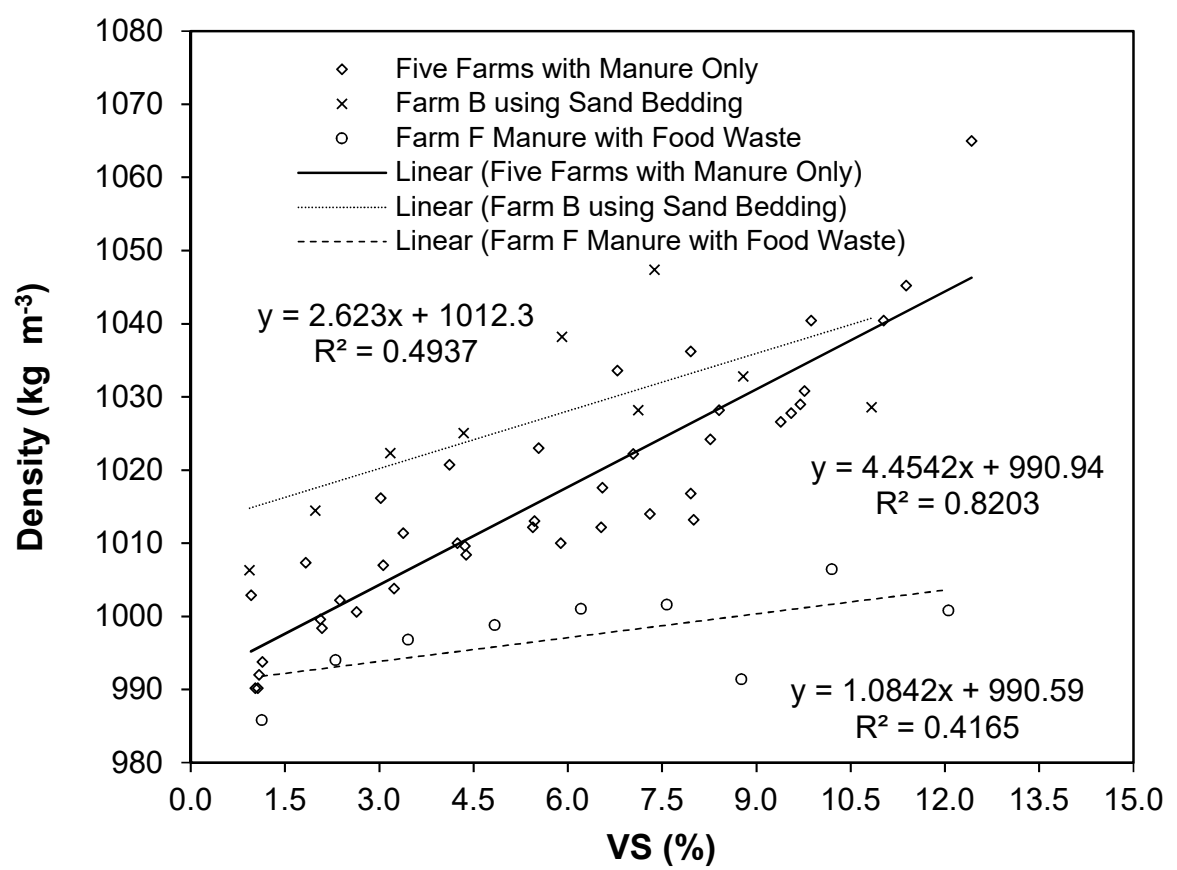

Figure 5. Density of pre-digested manure as a function of volatile solids (VS) content.

The VS content of post-digested manure was lower and had a larger variation compared with pre-digested manure, as shown in Figure 5. The post-digested manure VS/TS ranged from $70 \%$ to $80 \%$. The post-digested VS values are directly related to AD efficiency, or VS destroyed, which explains that all post-digested VS/TS values were reduced (Table 3). Greater VS destroyed indicates that the digester had a higher degradation efficiency as a greater percentage of the VS was converted to biogas [37]. The percentage of VS destroyed can be impacted by the original composition of pre-digested manure or the conditions within the digester (temperature, microorganisms, nutrients, etc.). By obtaining the density of pre- and post-digested manure, the VS content can be estimated by the model provided in Figures 5 and 6. The VS destroyed can be obtained by the difference between VS of pre-digested manure and post-digested manure. This methodology can be used to estimate biogas or methane production from $\mathrm{AD}$ systems with similar characteristics to those analyzed in this study.

Table 3. Volatile solids content for pre-digested and post-digested manure and volatile solids destroyed.

\begin{tabular}{cccccccc}
\hline & \multicolumn{3}{c}{ Pre-Digest } & \multicolumn{3}{c}{ Post-Digest } & \multirow{2}{*}{$\begin{array}{c}\text { Percentage of VS } \\
\text { Destroyed (\%) }\end{array}$} \\
\cline { 2 - 6 } & Slope & Intercept & Predicted VS (\%) & Slope & Intercept & Predicted VS (\%) & 6.07 \\
\hline A & 0.81 & -0.10 & 6.41 & 0.74 & 0.14 & 6.02 & 6.40 \\
B & 0.77 & 0.03 & 6.16 & 0.75 & -0.22 & 5.77 & 4.73 \\
C & 0.79 & 0.00 & 6.32 & 0.74 & 0.09 & 6.02 & 9.12 \\
D & 0.82 & -0.07 & 6.51 & 0.76 & -0.15 & 5.92 & 3.51 \\
E & 0.82 & -0.10 & 6.46 & 0.78 & 0.00 & 6.24 & 19.43 \\
F & 0.87 & -0.05 & 6.95 & 0.71 & -0.05 & 5.60 & 4.75 \\
G & 0.80 & -0.02 & 6.35 & 0.75 & 0.07 & 6.05 & \\
\hline
\end{tabular}






Figure 6. Density of post-digested manure as a function of volatile solids content.

\section{Conclusions}

Density, TS content, and VS content of unprocessed and processed dairy manure were analyzed. Results showed that TS and VS content of pre-digested dairy manure are linearly related to density for liquid manure. The density decreased with the increasing TS when TS was higher than $8.0 \%$. It is possible to estimate the TS and VS content of manure on a farm using the relationships presented in this paper by taking a simple mass and volume measurement. The VS content pre- and post-anaerobic digestion is linearly related to density.

Author Contributions: The authors contributed equally to this work.

Funding: This material is based on work that is supported by the National Institute of Food and Agriculture, United States Department of Agriculture under award number 2017-67003-26055. Any opinions, findings, conclusions, or recommendations expressed in this publication are those of the authors and do not necessarily reflect the view of the United States Department of Agriculture.

Acknowledgments: The authors would like to acknowledge Christian Burnson, Thomas Zimonick, Jacob Roundy, and Esmeralda Tovar for their help with sampling and analysis.

Conflicts of Interest: The authors declare no conflict of interest.

\section{References}

1. Ozlu, E.; Kumar, S. Response of Soil Organic Carbon, $\mathrm{pH}$, Electrical Conductivity, and Water Stable Aggregates to Long-Term Annual Manure and Inorganic Fertilizer. Soil Sci. Soc. Am. J. 2018, 82, 1243. [CrossRef]

2. Hadrich, J.C.; Harrigan, T.M.; Wolf, C.A. Economic comparison of liquid manure transport and land application. Appl. Eng. Agric. 2010, 26, 743-758. [CrossRef]

3. Veltman, K.; Rotz, C.A.; Chase, L.; Cooper, J.; Ingraham, P.; Izaurraldefg, R.C.; Jones, C.D.; Gaillard, R.; Larson, R.A.; Ruark, M.; et al. A quantitative assessment of Beneficial Management Practices to reduce carbon and reactive nitrogen footprints and phosphorus losses on dairy farms in the US Great Lakes region. Agric. Syst. 2018, 166, 10-25. [CrossRef]

4. Bentley, J.; Timms, L.L.; Tranel, L.F.; Lenth, R.A.; Lang, B.J.; Rieck-Hinz, A.; Brenneman, G.; Kohl, K.; Doran, B.E.; Breuerl, R.; et al. Economics of Dairy Manure Management in Iowa. 2016. Available online: http://ib.dr.iastate.edu/ans_air/vol662/iss1/36/ (accessed on 15 May 2019).

5. United States Environmental Protection Agency (USEPA). Inventory of U.S. Greenhouse Gas. Emissions and Sinks: 1990-2015; United States Environmental Protection Agency (USEPA): Washington, DC, USA, 2017.

6. Sharara, M.A.; Runge, T.; Larson, R.; Primm, J.G. Techno-economic optimization of community-based manure processing. Agric. Syst. 2018, 161, 117-123. [CrossRef] 
7. Hu, Y.; Scarborough, M.; Aguirre-Villegas, H.; Larson, R.A.; Noguera, D.R.; Zavala, V.M. A Supply Chain Framework for the Analysis of the Recovery of Biogas and Fatty Acids from Organic Waste. ACS Sustain. Chem. Eng. 2018, 6. [CrossRef]

8. Patterson, T.; Esteves, S.; Dinsdale, R.; Guwy, A. Life cycle assessment of biogas infrastructure options on a regional scale. Bioresour. Technol. 2011, 102, 7313-7323. [CrossRef] [PubMed]

9. Appels, L.; Lauwers, J.; Degrève, J.; Helsen, L.; Lievens, B.; Willems, K.; Van Impe, J.; Dewil, R. Anaerobic digestion in global bio-energy production: Potential and research challenges. Renew. Sustain. Energy Rev. 2011, 15, 4295-4301. [CrossRef]

10. Aguirre-Villegas, H.A.; Larson, R.A.; Reinemann, D.J. From waste-to-worth: Energy, emissions, and nutrient implications of manure processing pathways. Biofuels Bioprod. Biorefining 2014, 8, 770-793. [CrossRef]

11. Orzi, V.; Scaglia, B.; Lonati, S.; Riva, C.; Boccasile, G.; Alborali, G.L.; Adani, F. The role of biological processes in reducing both odor impact and pathogen content during mesophilic anaerobic digestion. Sci. Total Environ. 2015, 526, 116-126. [CrossRef]

12. Wilkie, A.C. Anaerobic Digestion of Dairy Manure: Design and Process Considerations. In Dairy Manure Management: Treatment, Handling and Community Relations (NRAES-176); Natural Resource, Agriculture, and Engineering Service: Ithaca, NY, USA, 2005; pp. 301-312.

13. Rotz, C.A.; Corson, M.S.; Chianese, D.S.; Montes, F.; Hafner, S.D.; Bonifacio, H.F.; Coiner, C. The Integrated Farm System Model-Reference Manual-Version 4.4. 2018. Available online: https://www.ars.usda.gov/ ARSUserFiles/80700500/Reference\%20Manual.pdf (accessed on 15 May 2019).

14. Hashimoto, A.G.; Varel, V.H.; Chen, Y.R. Factors affecting methane yield and production rate. In ASAE Paper No. 79-4583; ASAE: St. Joseph, MI, USA, 1979.

15. Agnew, J.M.; Leonard, J.J.; Feddes, J.; Feng, Y. A modified air pycnometer for compost air volume and density determination. Can. Biosyst. Eng. 2003, 45, 6.27-6.35.

16. Thirion, F.; Chabot, F.; Andeler, D. Physical characterisation of animal manure. In Proceedings of the 8 th International Conference on Management Strategies for Organic Waste Use in Agriculture, Rennes, France, 26-29 May 1998.

17. Glancey, J.; Adams, R. Applicator for sidedressing row crops with solid wastes. Trans. ASAE 1996, 39, 829-835. [CrossRef]

18. Houkom, R.; Butchbaker, A.; Brusewitz, G. Effect of moisture content on thermal diffusivity of beef manure. Trans. ASAE 1974, 17, 973-977. [CrossRef]

19. Chen, Y. Thermal properties of beef cattle manure. Agric. Wastes 1983, 6, 13-29. [CrossRef]

20. Achkari-Begdouri, A.; Goodrich, P.R. Bulk density and thermal properties of Moroccan dairy cattle manure. Bioresour. Technol. 1992, 40, 225-233. [CrossRef]

21. Landry, H.; Laguë, C.; Roberge, M. Physical and rheological properties of manure products. Appl. Eng. Agric. 2004, 20, 277-288. [CrossRef]

22. Landry, H.; Laguë, C.; Roberge, M.; Alam, M. Physical and flow properties of solid and semi-solid manure as related to the design of handling and land application equipment. In Proceedings of the AIC Meeting, Saskatoon, SK, Canada, 14-17 July 2002.

23. Houlbrooke, D.; Longhurst, B.; Orchiston, T.; Muirhead, R. Characterising Dairy Manures and Slurries; Hamilton: Ruakura, New Zealand, 2011.

24. Sobel, A. Physical properties of animal manures associated with handling. In Proceedings of the National Symposium Animal Waste Management, East Lansing, MI, USA, 13-15 May 1966.

25. U.S. Department of Agriculture (USDA). Dairy 2014, Dairy Cattle Management Practices in the United States; U.S. Department of Agriculture (USDA): Fort Collins, CO, USA, 2014.

26. Blayney DPDP. The Changing Landscape of U.S. Milk Production. 2002. Available online: https://www.ers. usda.gov/webdocs/publications/47162/17864_sb978_1_.pdf?v=41056 (accessed on 15 May 2019).

27. Scherer, P.A.; Vollmer, G.R.; Fakhouri, T.; Martensen, S. Development of a methanogenic process to degrade exhaustively the organic fraction of municipal 'grey waste' under thermophilic and hyperthermophilic conditions. Water Sci. Technol. 2000, 41, 83-91. [CrossRef] [PubMed]

28. Aguirre-Villegas, H.A.; Passos-Fonseca, T.H.; Reinemann, D.J.; Armentano, L.E.; Wattiaux, M.A.; Cabrera, V.E.; Norman, J.M.; Larson, R. Green cheese: Partial life cycle assessment of greenhouse gas emissions and energy intensity of integrated dairy production and bioenergy systems. J. Dairy Sci. 2015, 98, 1571-1592. [CrossRef] 
29. Thoma, G.; Popp, J.; Shonnard, D.; Nutter, D.; Matlock, M.; Ulrich, R.; Kellogg, W.; Kim, D.S.; Neiderman, Z.; Kemper, N.; et al. Regional analysis of greenhouse gas emissions from USA dairy farms: A cradle to farm-gate assessment of the American dairy industry circa 2008. Int. Dairy J. 2013, 31 (Suppl. 1), S29-S40. [CrossRef]

30. Rotz, A.C.; Montes, F.; Chianese, D.S. The carbon footprint of dairy production systems through partial life cycle assessment. J. Dairy Sci. 2010, 93, 1266-1282. [CrossRef]

31. Kramer, J. Wisconsin Agricultural Biogas Casebook. 2009. Available online: http://www.focusonenergy.com/ files/Document_Management_System/Renewables/biogas09_casestudy.pdf (accessed on 15 May 2019).

32. Greenberg, A.; Clesceri, L.; Eaton, A. Standard Methods for the Examination of Water and Wastewater, 18th ed.; American Public Health Association: Washington, DC, USA, 1992.

33. R Core Team. R: A Language and Environment for Statistical Computing; R Core Team: Vienna, Austria, 2013; ISBN 3-900051-07-0.

34. CSGNetwork. Specific Gravity Of General Materials Table. Available online: http://www.csgnetwork.com/ specificgravmattable.html (accessed on 5 March 2019).

35. Lorimor, J.; Powers, W.; Sutton, A. Manure Characteristics. In Manure Management Systems Series; Midwest Plan Service, Iowa State University: Ames, IA, USA, 2004.

36. El-Mashad, H.M.; Zhang, R. Biogas production from co-digestion of dairy manure and food waste. Bioresour. Technol. 2010, 101, 4021-4028. [CrossRef]

37. Mei, R.; Narihiro, T.; Nobu, M.K.; Kuroda, K.; Liu, W.T. Evaluating digestion efficiency in full-scale anaerobic digesters by identifying active microbial populations through the lens of microbial activity. Sci. Rep. 2016, 6, 1-10. [CrossRef] [PubMed]

(C) 2019 by the authors. Licensee MDPI, Basel, Switzerland. This article is an open access article distributed under the terms and conditions of the Creative Commons Attribution (CC BY) license (http://creativecommons.org/licenses/by/4.0/). 